\title{
EJECUCIÓN, LA PARTE DIFÍCIL DE LA ESTRATEGIA
}

\section{Gonzalo E. Guzmán Sanjinés}

\section{RESUMEN}

Si bien el desarrollo de las teorías sobre estrategia ha sido dramático, una parte crucial para el éxito de la estrategia viene a ser la ejecución. En este ensayo, se revisan las razones del fracaso de empresas tanto en la formulación como en la implantación de la estrategia. Se constata que para una buena ejecución es importante dotarse de recursos valiosos; para tener éxito en un mundo en constante cambio, las empresas deben ser capaces de reaccionar con presteza, el éxito en última instancia, radica en la capacidad del líder de integrar los recursos y capacidades a la implantación de la estrategia, creando así, un sistema de actividades que sea indescifrable para la competencia.

Palabras Clave: Estrategia, Ejecución, Inercia Activa, Liderazgo, Recursos. 